Pak. j. sci. ind. res. Ser. B: biol. sci. 2016 59(2) 80-84

\title{
Improvement of Amylase Production by UV Mutagenesis of Aspergillus flavus FSS63 under Solid State Fermentation
}

\author{
Samir Elkhouri and Yasser Bakri* \\ Department of Molecular Biology and Biotechnology, AECS, P. O. Box 6091, Damascus, Syria
}

(received February 2, 2015; revised November 5, 2015; accepted November 13, 2015)

\begin{abstract}
Enhancement of the amylase productivity by Aspergillus flavus was investigated. Spores of strain were exposed to ultraviolet (UVC) radiation and 10 different mutants were selected and isolated from starch plate agar on the basis of the visible clearance zone around the colonies. The amylase production by selected mutants was evaluated under solid state fermentation. One mutant of A. flavus FSS63UV8 showed higher biosynthesis level of amylase (733 IU/g), which was 3.35 fold higher than that detected in the parental strain. Physical parameters optimisation revealed that the optimum $\mathrm{pH}$ and temperature for amylase production obtained by mutant are 7.0 and $35^{\circ} \mathrm{C}$, respectively. Among several tested agricultural wastes, wheat bran was found to support the highest yield of amylase after 5 days of incubation. A. flavus FSS63UV8 strain proved to be a promising microorganism for a high amylase production in a simple medium.
\end{abstract}

Keywords: Aspergillus flavus, amylase, ultraviolet radiation

\section{Introduction}

Alpha amylase (EC3.2.1.1, 1,4- $\alpha$-D-glucan-glucanohydrolase) is an extracellular enzyme, which is involved in the starch processing industries where it breaks down starch into simple sugar constituents (Haq et al., 2002; Akpan et al., 1999). Amylase enzymes have also potential applications in a number of industries including brewing, baking, textile and detergent (Sundarram and Murthy, 2014; Gupta et al., 2003). Amylases constitute a class of industrial enzymes having approximately $25 \%$ of the enzyme market (Das et al., 2011). Today, new potential of using microorganisms as biotechnological source for production of industrially relevant enzymes has stimulated interest in exploring extra cellular enzymatic activity in several microorganisms (Gupta et al., 2003; Buzzini and Martini, 2002; Akpan et al., 1999). Amylases are generally found in animals, plants, bacteria and fungi and their sources in yeast, bacteria and fungi and their properties have already been reported earlier (Bedan et al., 2014; Singh et al., 2013; Liu and Xu, 2008 Chi et al., 2007). Among microorganisms, fungi have been recognized as a potential source of new enzymes with useful and/or novel characteristics (Singh et al., 2009). Moreover, amylases from fungal origin were found to be more stable when compared with the bacterial enzymes (Abu et al., 2005).

Several studies have been performed to investigate the *Author for correspondence; E-mail:ascientific@aec.org.sy use of different types of radiation on enzymatic activity of different microorganisms (Singh et al., 2013; Vladimirov et al., 2004). Improvement in enzymes production has been achieved through mutation, selection, or genetic recombination. However, in many cases, mutations are harmful, but occasionally may lead to a better adapted organism to its environment with improved bio-catalytic performance. The potential of a microorganism to mutate is an important property conferred by DNA, since it creates new variations in the gene pool. The real challenge is how to isolate those strains that are true mutants and thus carry the beneficial mutations (Parekh et al., 2000). UV rays are important inducers of strain mutations. The pyrimidines (thymine and cytosine) are especially sensitive to modifications by UV rays absorption. This may result in the production of thymine dimers that distorts the DNA helix and block future replications (Sambrook et al., 1989).

The objective of the present study was to improve the amylase production from Aspergillus flavus FSS63 through the use of ultraviolet radiation (UVC) as mutagenic agent and optimisation of cultural conditions.

\section{Materials and Methods}

Microorganism. Aspergillus flavus FSS63 utilized in this study was isolated from Syrian soil and identified in Center Wallon of Biology Industrial (CWBI), Belgium (Bakri et al., 2009). The fungus was grown on potatodextrose agar (PDA) plates at $30^{\circ} \mathrm{C}$. 
Ultra violet irradiation. The conidial suspension $10^{8}$ spore $/ \mathrm{mL}$ was prepared using sterile peptonic water, which consists of $5 \mathrm{~g} / \mathrm{L} \mathrm{NaCl}, 3 \mathrm{~g} / \mathrm{L}$ peptone, $1 \mathrm{~mL}$ tween 80 , and distilled water. Ten $\mathrm{mL}$ of this conidial suspension was irradiated by placing it in an opened sterilized plate which was on the inner base of ultraviolet radiation (UVC) apparatus (UVITEC) and $15 \mathrm{~cm}$ away from the UV lamps. The obtained dose was calculated based on this distance as $60 \mathrm{w} / \mathrm{m}^{2} \pm 5$. Serial dilutions were made up to $10^{4}$, then $100 \mu \mathrm{L}$ of the suspension was cultured on PDA plates. The same experiment was repeated changing the UVC exposure time to 10,15 , 20,25 and $30 \mathrm{~min}$. All plates were incubated at $30^{\circ} \mathrm{C}$ for $24-48 \mathrm{~h}$. The $\mathrm{D}^{10}$ was $20 \mathrm{~min}$. Every grown spore was separately cultured in a new plate and made a conidial suspension as the parent strain. All new isolates and the parent were evaluated for amylase production (Table 1).

Amylase production medium. Amylase was produced by culturing $1-\mathrm{mL}$ spore suspension $\left(10^{6}\right.$ spores $\left./ \mathrm{mL}\right)$ of each A. flavus isolates in Erlenmeyer flasks (100 $\mathrm{mL}$ ) containing $5 \mathrm{~g}$ of wheat bran as carbon source and mineral salt medium $\left(\mathrm{Na}_{2} \mathrm{HPO}_{4} .2 \mathrm{H}_{2} \mathrm{O}(1 \% \mathrm{~W} / \mathrm{V}), \mathrm{KCl}\right.$ $(0.05 \% \mathrm{~W} / \mathrm{V}), \mathrm{MgSO}_{4} .7 \mathrm{H}_{2} \mathrm{O}(0.015 \mathrm{~W} / \mathrm{V})$ and $(1 \%$ $\mathrm{W} / \mathrm{V})$ and $(0.5 \% \mathrm{~W} / \mathrm{V})$ yeast extract as nitrogen source. The $\mathrm{pH}$ was adjusted to 6.5 before sterilization. After inoculation, flasks were incubated at $30{ }^{\circ} \mathrm{C}$ for 5 days.

Amylase assay. $\alpha$-Amylase activity was determined as described by Okolo et al. (1995). Briefly the reaction mixture consisted of $1.25 \mathrm{~mL}$ of $1 \%$ soluble starch, $0.25 \mathrm{~mL}$ of $0.1 \mathrm{M}$ acetate buffer (pH 5.0), $0.25 \mathrm{~mL}$ of distilled water, and $0.25 \mathrm{~mL}$ of crude enzyme extract. After $10 \mathrm{~min}$ of incubation at $50{ }^{\circ} \mathrm{C}$, the liberated reducing sugars (glucose equivalents) were estimated by the dinitrosalicylic acid (DNS) method of Miller (1959). The blank contained $0.5 \mathrm{~mL}$ of $0.1 \mathrm{M}$ acetate buffer (pH 5.0), $1.25 \mathrm{~mL}$ of $1 \%$ starch solution and 0.25 $\mathrm{mL}$ of distilled water. One unit (IU) of $\alpha$-amylase is defined as the amount of enzyme releasing $1 \mu \mathrm{mol}$ glucose equivalent per minute under the assay conditions. All experiments were repeated twice in the same manner.

\section{Results and Discussion}

The effect of UVC exposure on Aspergillus flavus amylase production. The effect of UVC exposure of A. flavus FSS63 was tested at UV doses of 72, 90 and $108 \mathrm{~J} / \mathrm{cm}^{2}$ and a total of 10 colonies were selected on the basis of clear zones due to starch hydrolysis. At 90 $\mathrm{J} / \mathrm{cm}^{2}$ dose for $25 \mathrm{~min}, 1$ mutant strain named
AFFSS63UV4, was selected and showed an amylase production $626 \mathrm{IU} / \mathrm{g}$ which was 2.85 fold higher than the parental strain (Table 1). At $108 \mathrm{~J} / \mathrm{cm}^{2}$ dose for 30 min, 4 mutants were chosen to have an amylase production higher than their parents. One mutant strain AFFSS63UV8 produced $733 \mathrm{IU} / \mathrm{g}$ amylase which was around 3.35 fold higher than the parental strain.

Exposure of fungi spores to UV radiation produce mutant strains, this mutation depends on the type of damage in cell DNA, and on the mechanism of rebuilding this damage. Many researchers have used UV radiation to generate new mutant cells in order to increase enzymes production (Singh et al., 2013; Adsul et al., 2009; Bapiraju et al., 2004; Haq et al., 2002) and they succeeded in producing many mutant strains with higher enzyme production from many microorganisms such as Penicillium, Aspergillus, Trichoderma, Bacillus. Adsul et al. (2009) studied the effect of UV radiation on Penicillium janthinellum and isolated the mutant strains producing enhanced levels (3-5 folds) of FPA, CMCase, and xylanase in comparison to the parent strain. UV was also successfully used on Fusarium oxysporum and one mutant produced enzyme ability around $19.1 \mathrm{IU} / \mathrm{mL} / \mathrm{min}$ compared with the parental strain ability $13.1 \mathrm{IU} / \mathrm{mL} / \mathrm{min}$ (Singh et al., 1995). Bapiraju et al. (2004) also reported an increase in lipase enzyme production reaching $180 \%$ more by the mutant BTUV3 than the original strain of Rhizopus sp.BTS24.

The effect of $\mathbf{p H}$ on amylase production. Initial $\mathrm{pH}$ is one of the critical parameters, which correlates with the microbial growth directly. $\mathrm{pH}$ ranging from 3.0 to 8.0 was used to study its effect on amylase production by $A$. flavus FSS63UV8 was by varying the $\mathrm{pH}$ from 3.0 to 8.0. Results indicate that $\mathrm{pH} 7.0$ was found to be

Table 1. The Effect of UVC on the mutant of Aspergillus flavus FSS63 and its amylase production

\begin{tabular}{lll}
\hline \hline Dose J/cm2 & Mutant strain & Amylase ( IU/g) \\
\hline 0 & Parental strain & 219 \\
72 & AFFSS63UV1 & 187 \\
90 & AFFSS63UV2 & 209 \\
90 & AFFSS63UV3 & 196 \\
90 & AFFSS63UV4 & 626 \\
90 & AFFSS63UV5 & 186 \\
108 & AFFSS63UV6 & 622 \\
108 & AFFSS63UV7 & 162 \\
108 & AFFSS63UV8 & 733 \\
108 & AFFSS63UV9 & 512 \\
108 & AFFSS63UV10 & 612 \\
\hline \hline
\end{tabular}


the best for amylase activity (Fig. 1) and maximum amylase production was $(780 \mathrm{IU} / \mathrm{g})$. This might be due to an enhanced enzyme stability produced by the mutant strain. In contrast to these findings, Ivanova et al. (2001) achieved the optimal $\alpha$-amylase production at a $\mathrm{pH}$ range of 8.0-9.5. Puri et al. (2013) found that the highest enzymes production by $A$. oryzae was obtained at $\mathrm{pH}$ of 5.0. Changing the $\mathrm{pH}$ from the optimum to extreme levels results in inactivation of the enzymes of the organisms which hinder saccharification of the substrate (Silva et al., 2005).

The effect of incubation temperature on amylase production. Incubation temperature not only influences the growth of microorganisms but also their biological activities. Figure 2 reveals the effect of incubation temperature i.e. $25,30,35,40$ and $45{ }^{\circ} \mathrm{C}$ on amylase production by the mutant strain of $A$. flavus FSS63UV8 after 5 days of inoculation. It is clear from the results that a temperature of $35^{\circ} \mathrm{C}$ was found to be best suitable for amylase production. It might be due to the fact that $35^{\circ} \mathrm{C}$ is the optimal temperature for fungal growth and subsequently for enzyme production. In addition, high temperature might have reduced the moisture contents of the fermentation medium and organism growth resulting in a decreased enzyme production as pointed out by Markkanen and Suihko (1974).

The effect of carbon sources on amylase production. Different substrates like wheat bran, wheat straw, soybean cake, corn cobs hulls, potatoes peel, tomato pomace, beet pomace and cotton seed cake were used

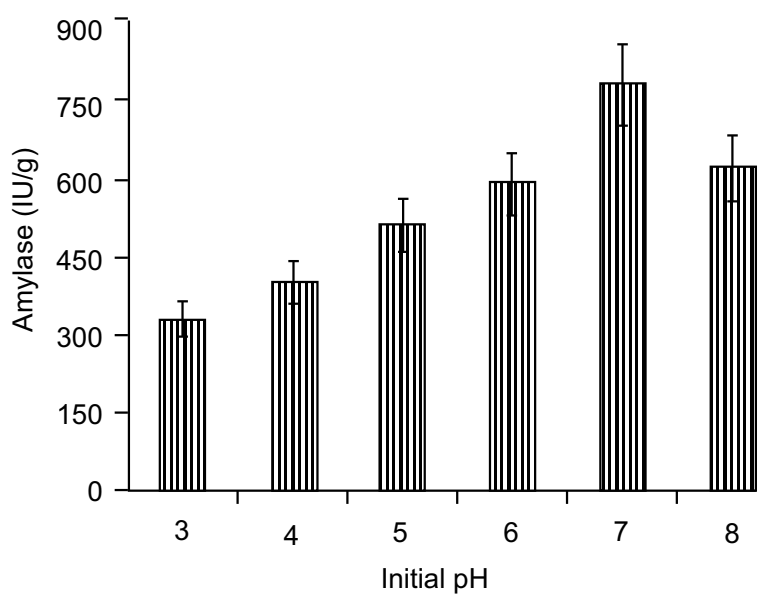

Fig. 1. Effect of $\mathrm{pH}$ on amylase production from A. flavus FSS6U8 mutant under solid state fermentation.

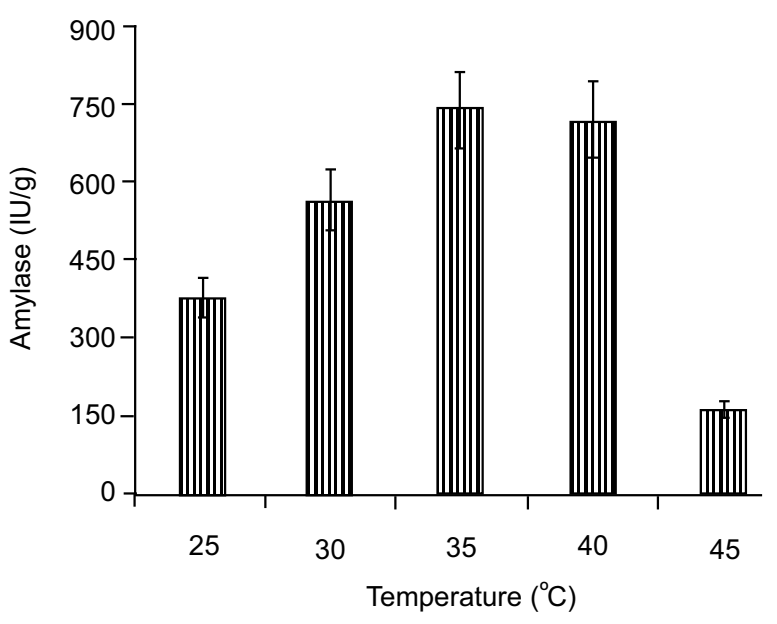

Fig. 2. Effect of incubation temperature on amylase prodution from A. flavus FSS63UV8 mutant under solid state fermentation

as carbon sources for amylase production by A.flavus FSS63UV8 under solid state fermentation. After inoculation and incubation for five days at $35{ }^{\circ} \mathrm{C}$, the enzyme was extracted using phosphate buffer and was estimated for enzyme activity. Among the various substrates screened for amylase production, wheat bran gave the highest enzyme activity followed by potatoes peel (Fig. 3). This indicates that the nature of carbon source in culture media is important for production of extracellular amylase (Vijayaraghavan et al., 2011; Teodoro and Martins, 2000). Similarly, wheat bran was found to be the best substrate for $\alpha$ - amylase production

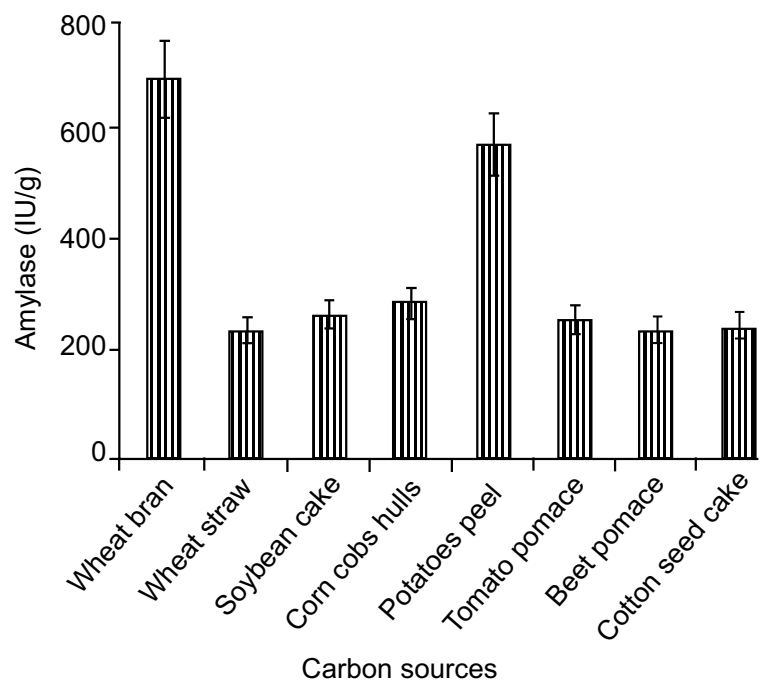

Fig. 3. Effect of carbon sources on amylase production from A. flavus FSS63UV8 mutant under solid state fermentation. 
by a thermophilic fungus Humicola lanuginose and $A$. niger (Singh et al., 2009). The highest activity in wheat bran may be due to its high carbohydrate contents and suitable texture.

\section{Conclusion}

In the present study, a mutant $A$. flavus FSS63UV8 was generated by UVC and proved to be an efficient producer of amylase under solid state fermentation. The optimal conditions for amylase production were $\mathrm{pH} 7$ and temperature $35^{\circ} \mathrm{C}$. Wheat bran was found to be less expensive substrate for an efficient amylase production $(733 \mathrm{IU} / \mathrm{g})$ after 5 days of incubation.

\section{Acknowledgement}

The authors would like to thank the Director General of AECS and the Head of Biotechnology Department for their help throughout the period of this research. Thanks are also extended to Dr. A. Aldaoude for critical reading of the manuscript.

\section{References}

Abu, E.A., Ado, S.A., James, D.B. 2005. Raw starch degrading amylase production of mixed culture of Aspergillus niger and Saccharomyces cerevisae grown on Sorghum pomace. African Journal of Biotechnology, 4: 785-790.

Adsul, M.G., Terwadkar, A.P., Varma, A.J., Gokhale, D.V. 2009. Cellulase from Penicillium janthinellum mutants: solid -state production and their stability in ionic liquids. BioResources, 4: 1670-1981.

Akpan, I., Bankole, M.O., Adesemowo, A.M. 1999. Production of $\alpha$ amylase by Aspergillus niger in a cheap solid medium using rice bran and agricultural material. Tropical Science, 39: 77-79.

Bakri, Y., Masson, M., Thonart, P. 2009. Isolation and Identification of a new fungal strain for amylase biosynthesis. Polish Journal of Microbiology, 58: 269-273.

Bapiraju, K.V.V.S.N., Sujatha, P., Ellaiah, P., Ramana, T. 2004. Mutation induced enhanced biosynthesis of lipase. African Journal of Biotechnology, 3: 618-621.

Bedan, D.S., Aziz, G.M., Al-Saady, A.J.R. 2014. Optimum conditions for $\alpha$ - amylase production by Aspergillus niger mutant isolate using solid state fermentation. Current Research in Microbiology and Biotechnology, 2: 450-456.

Buzzini, P., Martini, A. 2002. Extracellular enzymatic activity profiles in yeast and yeast like strains isolated from tropical environments. Journal of Applied Microbiology, 93: 1020-1025.

Chi, H.L.Z., Wang, X., Duan, X., Ma, L., Gao, L. 2007. Purification and characterization of extracellular amylase from the marine yeast Aureobasidium pullulans $\mathrm{N} 13 \mathrm{~d}$ and its raw potato starch digestion. Enzyme and Microbial Technology, 40: 1006-1012.

Das, S., Singh, S., Sharma, V, Soni, M.L. 2011. Biotechnological applications of industrially important amylase enzyme. International Journal of Pharma and BioSciences, 2: 486-496.

Gupta, R., Gigras, P., Mohapatra, H., Goswami, V. K., Chauhan, B. 2003. Microbial $\alpha$-amylase: a biotechnological perspective. Process Biochemistry, 38: 1599-1616.

Haq, I., Ashraf, H., Abdullah, R., Shah, A.H. 2002. Isolation and screening of fungi for the biosynthesis of alpha amylase. Biotechnology, 1: 61-66

Ivanova, V., Yankov, D., Kabaivanova, L., Pashkkoulov, D. 2001. Simultaneous biosynthesis and purification of two extra cellular Bacillus hydrolases in aqueous two-phase system. Microbiological Research 156: 19-30.

Liu, X.D, Xu, Y. 2008. A novel raw starch digesting $\alpha$-amylase from a newly isolated Bacillus sp. YX1: Purification and characterization. Bioresource Technology, 99: 4315-4320.

Markkanen, P.H., Suihko, M. L. 1974. The use of UVradiation in the improvement of enzyme production by Bacillus subtilis. Chemical Letters, 4: 89-92.

Miller, G. L. 1959. Use of dinitrosalicylic acid reagent for determination of reducing sugars. Analytical Chemistry, 31: 426-428.

Okolo, B. N., Ezeogu, L.I., Mba, C.N. 1995. Production of raw starch digestive amylase by Aspergillus niger grown on native starch source. Journal of the Science of Food and Agriculture, 69:109-115.

Parekh, S., Vinci, V.A., Strobel, R.J. 2000. Improvement of microbial strains and fermentation processes. Applied Microbiology and Biotechnology, 54: 287 301.

Puri, S., Arora, M., Sarao, L. 2013. Production and optimization of amylase and glucoamylase using Aspergillus oryzae under solid state fermentation. International Journal of Research in Pure and Applied Microbiology, 3: 83-88.

Sambrook, J., Fritsch, E.F., Maniatis, T. 1989. Molecular Cloning: A Laboratory Manual, 999 pp. 3rd edition, Cold Spring Harbor Laboratory, Cold Spring Harbor Press, New York, USA. 
Silva, E.D., Gomes, E., Souza, S.R., Grandi, R.P. 2005. Production of thermostable glucoamylase by newly isolated Aspergillus flavus A.1.1 and Thermomyces lanuginosus A 13.37. Brazilian Journal of Microbiology, 36: 75-82.

Singh, A., Kuhad, R.C., Kumar, M. 1995. Xylanase production by a hyperxylanolytic mutant of Fusarium oxysporum. Enzyme and Microbial Technology, 17: 551-553.

Singh, R.K., Kumar, S., Kumar. S. 2009. Production of $\alpha$-amylase from agricultural byproducts by Humicola lanuginosa in solid state fermentation. Current Trends in Biotechnology and Pharmacy, 3:172-180.

Singh, S., Sharma, V., Soni, M.L., Sinha, S.D. 2013. Effect of UV induced mutation on amylase producing potential of Bacillus subtilis (2620). International Journal of Pharma and Bio Sciences,
4: $62-68$.

Sundarram, A., Murthy, T.P.K. 2014. $\alpha$-Amylase production and applications: A review. Journal of Applied \& Environmental Microbiology, 2: 166-175.

Teodoro, C.E.D., Martins, M.L.L. 2000. Culture conditions for the production of thermostable amylase by Bacillus sp. Brazilian Journal of Microbiology, 31: 288-302.

Vijayaraghavan, P., Remya, C.S., Vincent, P. 2011. Production of $\alpha$-amylase by Rhizopus microspora using agricultural by-product in solid state fermentation. Research Journal of Microbiology, 6: $366-375$.

Vladimirov, Y.A., Osipov, A.N., Klebanov, G.I. 2004. Photobiological principles of therapeutic applications of laser radiation. Biochemistry, 69: 81-90. 